\title{
Chronic crude garlic-feeding modified adult male rat testicular markers: mechanisms of action

\author{
Imen Hammami ${ }^{1,2}$, Souheila Amara ${ }^{2}$, Mohamed Benahmed ${ }^{2}$, Michèle V El \\ May ${ }^{1}$ and Claire Mauduit*3
}

\begin{abstract}
Address: ${ }^{1}$ Unité de recherche n 01/UR/08-07, Faculté de Médecine, 15 rue Djebel Lakhdar, 1007 Tunis; Tunisie, 2 Inserm, U407, Oullins, F-69921, France; Université de Lyon, Oullins, F-69921, France; Université Lyon 1, Oullins, F-69921, France and ${ }^{3}$ Hospices Civils de Lyon, Centre Hospitalier Lyon-Sud, Laboratoire d'Anatomie et de Cytologie Pathologique, Pierre-Bénite Cedex F-69495, France

Email: Imen Hammami - hammamiimen@hotmail.fr; Souheila Amara - asouheila@yahoo.fr;

Mohamed Benahmed - mohamed.benahmed@unice.fr; Michèle V El May - elmay_michele@yahoo.fr; Claire Mauduit* - mauduit@sante.univlyon1.fr

* Corresponding author
\end{abstract}

Published: 24 June 2009

Reproductive Biology and Endocrinology 2009, 7:65 doi:10.1/86/1477-7827-7-65

This article is available from: http://www.rbej.com/content/7///65

(C) 2009 Hammami et al; licensee BioMed Central Ltd.

This is an Open Access article distributed under the terms of the Creative Commons Attribution License (http://creativecommons.org/licenses/by/2.0), which permits unrestricted use, distribution, and reproduction in any medium, provided the original work is properly cited.
Received: 20 December 2008

Accepted: 24 June 2009

\begin{abstract}
Background: Garlic or Allium sativum (As) shows therapeutic effects such as reduction of blood pressure or hypercholesterolemia but side-effects on reproductive functions remain poorly investigated. Because of garlic's chemical complexity, the processing methods and yield in preparations differ in efficacy and safety. In this context, we clarify the mechanisms of action of crushed crude garlic on testicular markers.
\end{abstract}

Methods: During one month of treatment, 24 male rats were fed 5\%, 10\% and I5\% crude garlic.

Results: We showed that crude garlic-feeding induced apoptosis in testicular germ cells (spermatocytes and spermatids). This cell death process was characterized by increased levels of active CASP3 but not CASP6. Expression of the caspase inhibitors BIRC3 and BIRC2 was increased at all doses of As while expression of XIAP and BIRC5 was unchanged. Moreover, expression of the IAP inhibitor DIABLO was increased at doses $10 \%$ and I5\% of As. The germ cell death process induced by As might be related to a decrease in testosterone production because of the reduced expression of steroidogenic enzymes (Star, Cypl la, Hsd3b5 and Hsdl7b). Evaluation of Sertoli markers showed that TUBB3 and GSTA2 expression was unchanged. In contrast, AMH, RHOX5 and CDKNIB expression was decreased while GATA4 expression was increased.

Conclusion: In summary, we showed that feeding with crude garlic inhibited Leydig steroidogenic enzyme expression and Sertoli cell markers. These alterations might induce apoptosis in testicular germ cells.

\section{Background}

Allium sativum (As) or garlic is a popular spice usually eaten both raw and cooked in various doses and its potential medical properties have been recognized for thou- sands of years [1,2]. Garlic is one of the ten commonest herbal medicines used in the United States (ranked in fifth place), according to recent sales data (for a review see, [3]). Indeed, As displays therapeutic effects such as in the 
treatment of hypercholesterolemia [4,5], prevention of arteriosclerosis $[6,7]$ and some cancers $[8,9]$, and presents anticoagulant $[10,11]$ and antihypertensive [12] properties. For example, non-pharmacological treatment with garlic preparation is suggested to reduce blood pressure in hypertensive individuals (for a review, see [13]). The sideeffects, particularly on male reproduction, of such a chronic treatment are poorly investigated. To date, it has been reported that heated garlic juice was effective in recovery of testicular function after experimental testicular hypogonadism [14] but other laboratories have reported that powder [15] or crude [16] garlic preparations impaired testicular and male reproductive tract functions. Moreover, garlic metabolites such as diallyl trisulfide have been reported to have spermicidal effects $[17,18]$. The mechanisms of garlic action on male reproduction function, and particularly on spermatogenesis, however, remain unknown.

In the present study, we investigated the mechanisms of action of chronic consumption of crude garlic on testicular functions. We tried to identify the cellular and molecular targets of crude garlic administrated in various doses to adult male rats.

The last step of apoptosis, before the irreversible cleavage of crucial proteins and endonuclease activation, is under the control of effector caspases named Caspase 3, 6 or 7 . Caspase 3 (CASP3) has been studied extensively and is known to be synthesized as a pro-enzyme which needs cleavage to be active [for a review, see [19]). Activation and/or activity of CASP3, 7 or 9 is regulated by the Inhibitors of Apoptosis Proteins (IAPs). IAPs share a common domain known as BIR (baculovirus IAP repeat), that binds to and inhibits CASP3, 7 or $9[20,21]$. Among the IAP family are XIAP, BIRC3 (previously known as c-IAP1), BIRC2 (previously known as c-IAP2) and BIRC5 (previously known as Survivin) [22]. A third level of regulation has also been observed. IAP action can be inhibited by mitochondrial proteins such as DIABLO [23-25]. Therefore, the fate of the cell at the executioner step of apoptosis depends on the relative quantity of each actor: effector caspase; IAPs and IAP inhibitors, such as DIABLO. In addition to the caspase pathway, the AIFM1 (Apoptosisinducing factor mitochondrion-associated 1) exists, which is a phylogenetically ancient mitochondrial intermembrane flavoprotein endowed with the unique capacity to induce caspase-independent peripheral chromatin condensation and large-scale DNA fragmentation when added to purified nuclei [26].

\section{Methods \\ Materials}

TRIzol $^{\circledR}$, Moloney murine leukemia virus (M-MLV) reverse transcriptase and deoxynucleotide triphosphates (dNTPs) were obtained from Life Technologies, Inc. (Eragny, France). Protease-inhibitor cocktail, calf thymus deoxynucleotidyl terminal transferase and biotin 16-deoxyuridine 5-triphosphate (16-dUTP) were obtained from Roche Molecular Biochemicals (Mannheim, Germany). Sigma (Meylan, France) was the source for random hexanucleotides, acrylamide/bisacrylamide 37.5/1, Biomax MR films, deoxyribonuclease I (DNase I), ACTIN antibody (A5060), diaminobenzidine (DAB), nickel chloride, cobalt chloride, sodium cacodylate and Fast Red. Taq polymerase was purchased from Promega Corp. (Madison, WI, USA). Bovine serum albumin (BSA) was purchased from Euromedex (Souffelweyersheim, France). The SuperSignal ${ }^{\circledR}$ West Pico Chemiluminescent kit was obtained from Pierce (Perbio Science, Brebières, France). CASP3 (9661), CASP6 (9762) antibodies were obtained from Ozyme (Saint Quentin en Yvelines, France). BIRC3 (sc-7943), BIRC2 (sc-7944), BIRC5 (sc-10811), active AIFM1, DIABLO (sc-12683), GATA-4 (GATA binding protein 4), AMH (Anti-Müllerian Hormone) and RHOX5 (reproductive homeobox 5, previously known as PEM) were obtained from Santa Cruz Biotechnology (Santa Cruz, CA, USA). Antibodies raised against XIAP (X-linked inhibitor of apoptosis) and against CDKN1B (cyclindependent kinase inhibitor $1 \mathrm{~B}$, previously known as p27kip1) were obtained from BD Sciences Pharmingen (Pont de Claix, France). GSTA2 antibody (Glutathione Stransferase alpha2, NCL-GSTa) was obtained from Novocastra Laboratories (Rungis, France). Antibody raised against TUBB3 (Tubulin beta3, clone TUJ1) was obtained from R\&D Systems Europe (Lille, France). Oligonucleotide primers were purchased from Proligo SAS (Paris, France). Envision ${ }^{+}$kit (mouse or rabbit), hematoxylin and Faramount ${ }^{\circledR}$ were obtained from Dako (Trappes, France). UltraProbe Basic Reagent 2 was purchased from Biomeda (Burlingame, CA). Superfrost Plus glass slides were obtained from Menzel-Glaser (Frelburg, Germany). The English edition of the manuscript was checked by a professional proofreading service (Proof-Reading-Service.org, Hertfordshire, United Kingdom).

\section{Plant preparation}

The type of As used in the present study was "spring garlic". It has pink bulbs and is planted between December and March (according to the weather) in Tunisia and collected in July. This type of garlic contains $2.1 \%$ of proteins, $30 \%$ of carbohydrates, $1.5 \%$ of fibres, $0.2 \%$ of fat, $0.015 \%$ of vitamins and $0.7 \%$ minerals. The As plant used in this study was grown in Tunisia and purchased from a local market. Every day the garlic pellets were made by mixing peeled cloves of garlic with powdered standard rat pellet diet (Industrial Society of Food, Sfax, Tunisia) at three doses: $5 \%, 10 \%$ and $15 \%$. For example, $15 \%$ pellets for one rat were prepared by mixing $4.5 \mathrm{~g}$ of crude garlic with $25.5 \mathrm{~g}$ of powdered standard diet in $5 \mathrm{~mL}$ of water. 
Cloves were crushed in distilled water in order to minimize volatile compound loss. A similar volume of water was added to the other doses [16].

\section{Animal treatments}

A total of 24 adult male rats of Wistar strain were used for the study as previously described [16]. Control animals received standard pellet diet $(0 \%)$. The other groups received diet supplemented with 5\%,10\% and 15\% of As. Every day, $30 \mathrm{~g}$ of food (garlic mixed with standard diet) was given to each rat. After 30 days of treatment the rats were sacrificed by decapitation. Testes were weighed and dissected. For each animal, the first testis was fixed in formaldehyde followed by routine paraffin embedding for TUNEL and immunohistochemical analysis; the second testis was frozen at $-80^{\circ} \mathrm{C}$ for molecular and Western blot analyses. All studies on animals were conducted in accordance with current regulation and standards approved by the Faculty of Medicine of Tunis Animal Care Committee.

\section{Study design}

In the present study, we investigated the effects of chronic consumption of crude garlic on testicular markers. First, apoptosis through TUNEL and CASP3 immunostaining approach was analyzed. In the following experiments, we have examined how treatment with As could induce changes in the expression of effector CASP3 and 6, of their cellular inhibitors (XIAP, BIRC2, BIRC3 and BIRC5) and mitochondrial pro-apoptotic factors (DIABLO and AIFM1). Since germ cell apoptosis might be linked to impairment of gonadotropin delivery and/or Leydig or Sertoli cell dysfunction, we have further evaluated these aspects.

\section{TUNEL (TdT-mediated dUTP-X Nick End Labeling)}

Paraffin sections ( $5 \mu \mathrm{m}$ ) of formaldehyde-fixed testicular tissues were mounted onto Superfrost Plus slides. The sections were handled as previously described [27]. For each rat testis at least 100 random seminiferous tubules were numbered. The results were expressed as the apoptotic rate, i.e. the number of TUNEL positive cells per number of Sertoli cells.

\section{Immunohistochemistry}

Paraffin sections were incubated for $20 \mathrm{~min}$ at $93^{\circ}-98^{\circ} \mathrm{C}$ in citric buffer $(0.01 \mathrm{M}, \mathrm{pH} 6)$ and left to cool for $20 \mathrm{~min}$ at room temperature. The sections were rinsed twice for 5 min in osmosed water, and washed twice for $5 \mathrm{~min}$ in Trisbuffered saline (TBS) containing $0.1 \%$ Tween-20. The Envision+ kit was used for detection of anti-cleaved CASP3 antibody (dilution 1/50) according to the manufacturer's recommendations. The antigen-antibody complexes were stained with $\mathrm{DAB}$ which generated a brown color at the site of peroxidase activity. The sections were rinsed twice for 5 min in osmosed water, counterstained with hematoxylin for 5 min and mounted in Faramount ${ }^{\circledR}$.

\section{RNA extraction and Reverse Transcription-Polymerase Chain Reaction (RT-PCR) coamplification}

Total RNA were extracted from testicular tissues with TRI$\mathrm{zol}^{\circledR}$ reagent according to the manufacturer's recommendations. The amount of RNA was estimated by spectrophotometry at $260 \mathrm{~nm}$. The cDNAs were obtained by reverse transcription of $5 \mu \mathrm{g}$ of total RNAs using random hexanucleotides as primers $(5 \mu \mathrm{M})$ in the presence of dNTP $(200 \mu \mathrm{M})$, dithiothreitol $(10 \mathrm{mM})$ and M-MLV reverse transcriptase $(200 \mathrm{U} / \mu \mathrm{l})$ for $1 \mathrm{~h}$ at $37^{\circ} \mathrm{C}$. For the PCR analysis, the target genes Star (Steroidogenesis activator protein), Cyp11a1 (previously known as P450 cholesterol side-chain cleavage), $H s d 3 b 5$ (previously known as 3-beta-hydroxysteroid dehydrogenase), Hsd17b3 (17beta-hydroxysteroid dehydrogenase), Cyp19a1 (previously known as P450 aromatase) and Srd5a2 (previously known as 5alpha-reductase) were coamplified with the standard housekeeping gene Actb (beta-actin), in the presence of $2 \mu \mathrm{l}$ of cDNA mixture, $0.02 \mathrm{U} / \mu \mathrm{l}$ of Taq polymerase, $1 \mu \mathrm{M}$ of target primers, 0.5 to $1 \mu \mathrm{M} A c t b$ primers, 1.5 $\mathrm{mM} \mathrm{MgCl} 2,100 \mu \mathrm{M}$ dNTPs and $0.075 \mu \mathrm{l}$ of $\left[\alpha^{-33 P}\right] \mathrm{dATP}$. The PCR amplification was performed by first heating the mixture at $95^{\circ} \mathrm{C}$ for 5 min followed by several cycles (see Table 1) consisting of three steps: one at $95^{\circ} \mathrm{C}$ for $30 \mathrm{sec}$, a step at melting temperature (Tm, see Table 1) for $30 \mathrm{sec}$ and a step at $72^{\circ} \mathrm{C}$ for $30 \mathrm{sec}$. The PCR reaction ended with a step at $72^{\circ} \mathrm{C}$ for $5 \mathrm{~min}$. After amplification, the coamplified PCR products for the target and the standard genes were separated onto an $8 \%$ polyacrylamide gel. The gel was dried and exposed on a phosphor screen (Packard, Meriden, CT) for about $30 \mathrm{~min}$ to $1 \mathrm{~h}$. The phosphor screen was scanned by a cyclone phosphorimager (Packard, Meriden, CT) and the band intensities for each PCR product were quantified with OptiQuant software (Packard, Meriden, CT). The data were expressed as a target gene/Actb mRNA ratio. The sequences for the primers are reported in Table 1 . The PCR reactions were conducted within the logarithmic phase of amplification. The PCRamplified products were checked by direct sequencing. The RT-PCR primers were designed inside separate exons to avoid any bias caused by residual genomic contamination. Moreover, for all primers, no amplification was observed when PCR was performed on RNA preparations.

\section{Western blotting analyses}

Proteins were obtained from testicular tissues as previously described [16]. Proteins $(15-40 \mu \mathrm{g})$ were resolved on a $10 \%-15 \%$ sodium dodecyl sulfate/polyacrylamide gel. Proteins were electrophoretically transferred to a nitrocellulose membrane using $25 \mathrm{mM}$ Tris - $185 \mathrm{mM}$ glycine buffer ( $\mathrm{pH} 8.3$ ) containing 20\% methanol at a constant voltage of $100 \mathrm{~V}$ for $1 \mathrm{~h}$. After transfer, the 
Table I: Primer sequences and PCR conditions

\begin{tabular}{|c|c|c|c|c|}
\hline Primer Names & Primer Sequences (Forward And Reverse) & $\begin{array}{l}\text { Mealting Temperature } \\
\left({ }^{\circ} \mathrm{C}\right)\end{array}$ & Cycles & PCR Product Length $(\mathrm{BP})$ \\
\hline Star & $\begin{array}{l}\text { 5'-ATGTTCCTCGCTACGTTCAAG-3' } \\
\text { 5'-CTTCCAGCCAGTGGATGAAGC-3' }\end{array}$ & 57 & 33 & 695 \\
\hline Cypl Ial & $\begin{array}{l}\text { 5'-AGGTGTAGCTCAGGACTTCA-3' } \\
\text { 5'-AGGAGGCTATAAAGGACACC-3' }\end{array}$ & 64 & 24 & 399 \\
\hline $\mathrm{Hsd} 3 \mathrm{~b} 5$ & $\begin{array}{l}\text { 5'-TCACATGTCCTACCCAGG-3' } \\
\text { 5'-ATTTTTCAGGATGCTCCC-3' }\end{array}$ & 62 & 26 & 264 \\
\hline HsdI 7b3 & $\begin{array}{l}\text { 5'-TTCTGCAAGGCTTTACCAGG-3' } \\
\text { 5'-ACAAACTCATCGGCGGTCTT-3' }\end{array}$ & 55 & 30 & 653 \\
\hline Srd5a2 & $\begin{array}{l}\text { 5'-CAATCCTGCAAGATTCCACC-3' } \\
\text { 5'-ATTGGTCCTTGGGTGCATTC-3' }\end{array}$ & 52 & 26 & 380 \\
\hline Cypl9al & $\begin{array}{l}\text { 5'-GCTTCTCATCGCAGAGTATCCGG-3' } \\
\text { 5'-CAAGGGTAAATTCATTGGGCTTGG-3' }\end{array}$ & 52 & 32 & 289 \\
\hline Actb & $\begin{array}{l}\text { 5'-TTGCTGATCCACATCTGCTG-3' } \\
\text { 5'-GACAGGATGCAGAAGGAGAT-3' }\end{array}$ & according to target gene & & 146 \\
\hline
\end{tabular}

membranes were incubated in a blocking buffer (TBS containing $1 \%$ of BSA and $0.1 \%$ Tween-20) for $2 \mathrm{~h}$ at room temperature. The membranes were rinsed three times with TBS/0.1\%Tween-20 for 10 min each, and incubated with the first antibody (in TBS containing 1\% of BSA) overnight at $4{ }^{\circ} \mathrm{C}$. The antibodies were diluted as follows: $1 /$ 100 for GATA-4 and AMH; $1 / 200$ for RHOX5 and CASP3; $1 / 400$ for BIRC3 and BIRC5; $1 / 500$ for CDKN1B; $1 / 600$ for DIABLO; $1 / 1,000$ for CASP6 and GSTA $2 ; 1 / 2,500$ for BIRC2; $1 / 3,000$ for TUBB3 and $1 / 6,000$ for XIAP. The protein loading was checked by probing the blot with a rabbit IgG anti-ACTIN antibody $(1 / 20,000)$. The antigen-antibody complexes were detected with a chemiluminescent kit. The membranes were exposed on Biomax MR films. The intensity of the bands was determined with OptiQuant software. The data were expressed as a target/actin protein ratio.

\section{Data analysis}

The results are expressed as the mean \pm SD. For each condition, at least six different rats were used. A one-way analysis of variance (ANOVA) for independent groups was performed to determine whether there were differences between all groups and this was followed by the Bonferroni post hoc test at $\mathrm{p}<0.05$ to determine the significance ( $\mathrm{p}<0.05$ ) of the differences between the pair of groups. The statistical tests were performed on StatView software version 5.0 (SAS Institute Inc., Cary, NC).

\section{Results}

\section{Effects of As treatment on germ cell apoptosis}

Treatment with As induced a cell death process in the adult rat testis as shown by the TUNEL approach. In the control untreated animals, very few apoptotic germ cells were observed (Fig. 1A), whereas TUNEL-positive cells were identified in rat testis treated with $15 \%$ of As (Fig.
1B). These TUNEL-positive cells were mainly spermatocytes and spermatids (Fig. 1B). The number of apoptotic germ cells in rat testes increased after treatment with As in a dose-dependent manner (Fig. 2A). A significant ( $p<$ $0.0001)$ increase was observed in the rats treated with $10 \%$ and $15 \%$ of As. The cell death process induced in spermatocytes and spermatids from rats fed with As was probably an apoptotic mechanism, since an immunostaining for cleaved CASP3 was detected in these cells (Fig. 1D) while only a few stained germ cells were detected in untreated rats (Fig. 1C).

\section{Effects of As feeding on the executioner step of apoptosis in the adult rat testis}

Cleaved CASP3 expression was increased in a dosedependent manner in the testicular tissues from rats fed with As with a significant increase at doses $10 \%(26 \%, p=$ $0.0003)$ and $15 \%(29 \%, p<0.0001$; Fig. $2 B)$. In contrast, As-feeding did not modify the expression of cleaved CASP6 (Fig. 2C). The BIRC3 protein levels were significantly increased at doses 5\% (30.5\%; $p<0.01), 10 \%$ $(29 \% ; p<0.02)$ and $15 \%(36 \% ; p<0.003)$ of As (Fig. 3A). Similarly, the BIRC2 protein levels were significantly increased after treatment with 5\% (29\%; $p<0.002), 10 \%$ $(31.5 \% ; p<0.004)$ and 15\% (37\%; $p<0.0003)$ of As (Fig. $3 \mathrm{~B})$. In contrast, As-feeding did not modify the protein levels of XIAP (Fig. 3C) or BIRC5 (Fig. 3D) at the different tested doses. We then evaluated the third partner of the executioner step of apoptosis, i.e. the IAP inhibitor DIABLO. Its protein levels were increased significantly at doses $10 \%(21 \% ; p<0.02)$ and $15 \%(21.5 \% ; p<0.02)$ (Fig. 3E). The apoptotic cell death process can also be induced by a caspase-independent pathway represented by AIFM1. In the testicular tissue from rats fed with As, the expression of active AIFM1 protein (Fig. 3F) levels was unchanged at the different tested doses. 
A

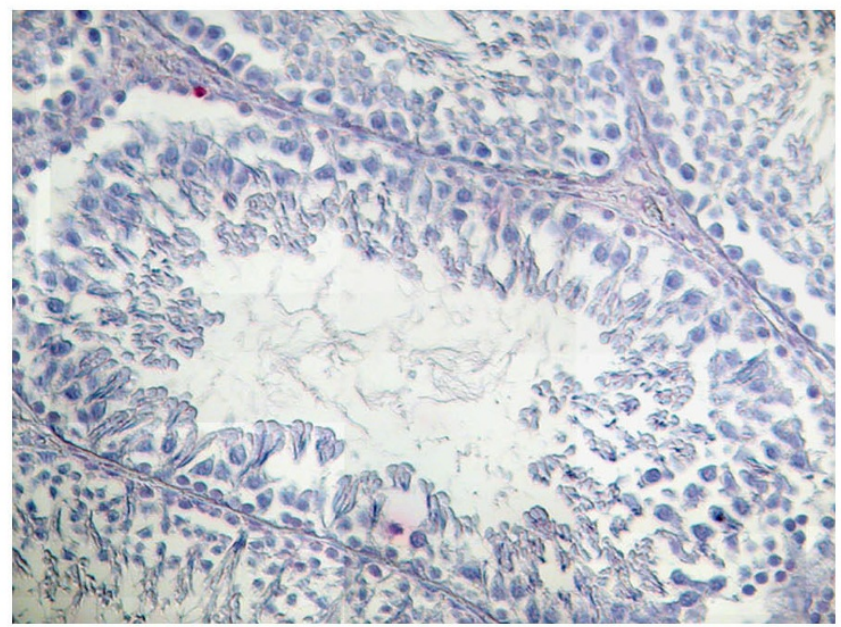

C

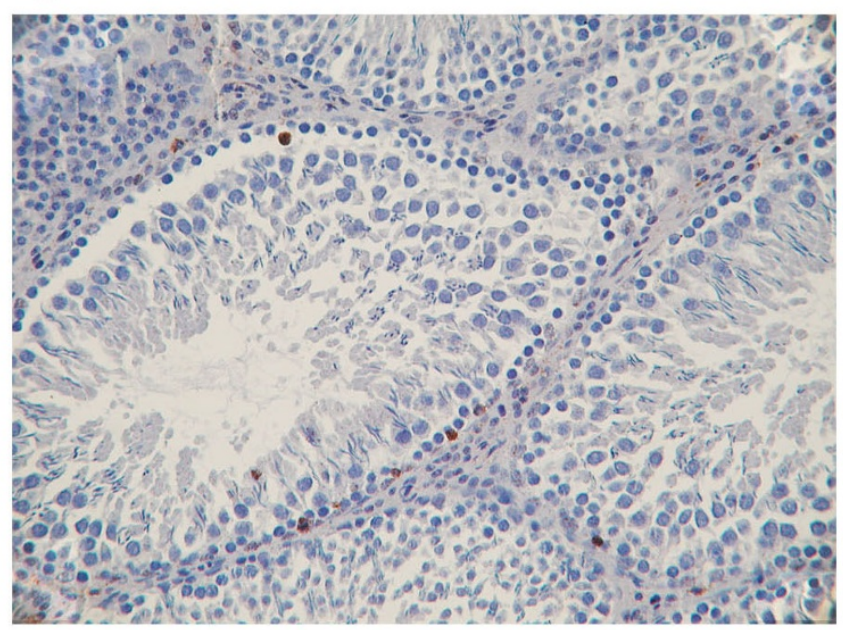

B

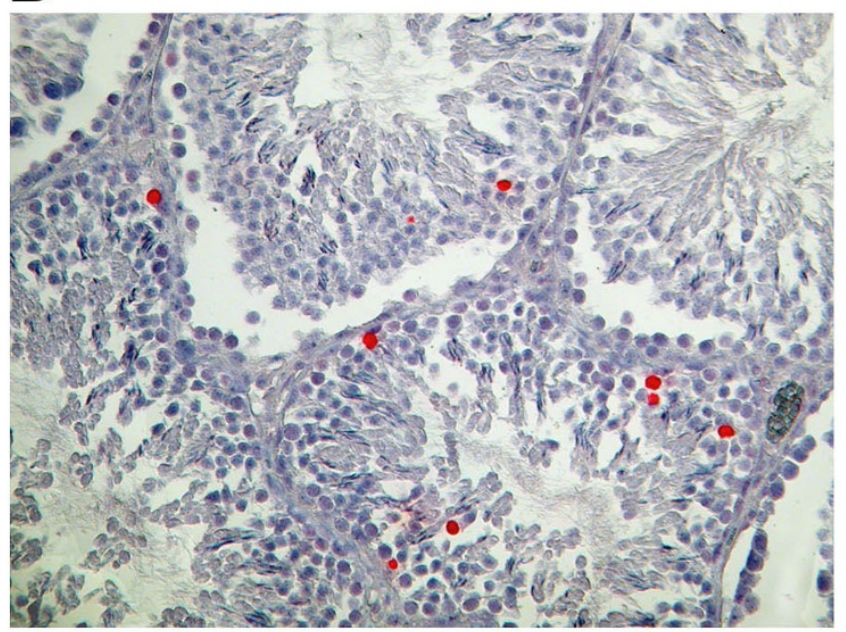

D

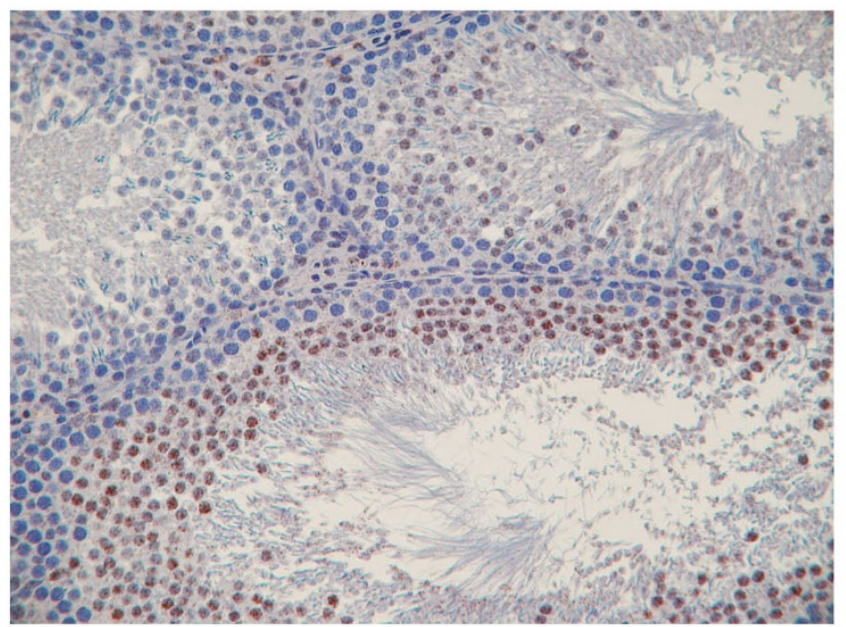

\section{Figure I}

As-induced apoptosis in germ cells (TUNEL AND CASP3 immunostaining). Testes from untreated rats (A, C) or adult rats fed with $15 \%$ As $(B, D)$. Detection of apoptotic cells was conducted through the TUNEL approach (A, B) and cleaved CASP3 immunostaining (C, D) (magnification $=\times 200$ ). Red staining reveals the TUNEL positive nuclei and brown staining reveals the CASP3 cytoplasm immunostaining.

\section{Effects of treatment with As on plasma hormone levels} In a previous report, we showed that As significantly decreased plasma and intratesticular testosterone levels, while a significant increase in LH levels was observed, but the FSH was not investigated [16]. We show here that FSH plasma levels were significantly decreased (about 19.7\%) at doses $10 \%$ (without As $12.7 \pm 1.91 \mathrm{ng} / \mathrm{mL}$; vs. with $10 \%$ As $10.22 \pm 1.6 \mathrm{ng} / \mathrm{mL} ; p=0.03)$ and $15 \%(10.18 \pm$ $1.17 \mathrm{ng} / \mathrm{mL} ; p=0.04$ ) of As.

\section{Effects of treatment with As on Leydig cell steroidogenic enzyme expression}

The mRNA levels for Star, Cyp11a1, Hsd3b5 and Hsb17b3 were decreased in a dose-dependent manner (Fig. 4). The Star mRNA levels were significantly decreased (Fig. 4A) in testicular tissue from rats treated with $5 \%(16 \% ; p=0.02)$, $10 \%(64.5 \% ; p<0.0001)$ and 15\% (66\%; $p<0.0001)$ of As. Similarly, Cyp11a1 ( $p<0.0001$, Fig. 4B) and Hsd3b5 $(p<0.0001$, Fig. 4C) mRNA levels were significantly decreased at the different doses of crude garlic tested. The Hsb17b3 mRNA levels were significantly decreased at doses 5\% (25\%; $p<0.004), 10 \%(37 \% ; p<0.002)$ and 


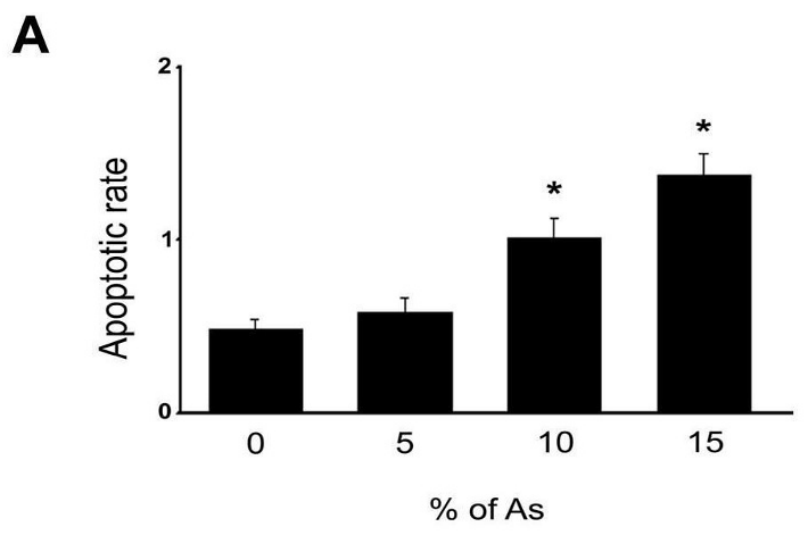

B
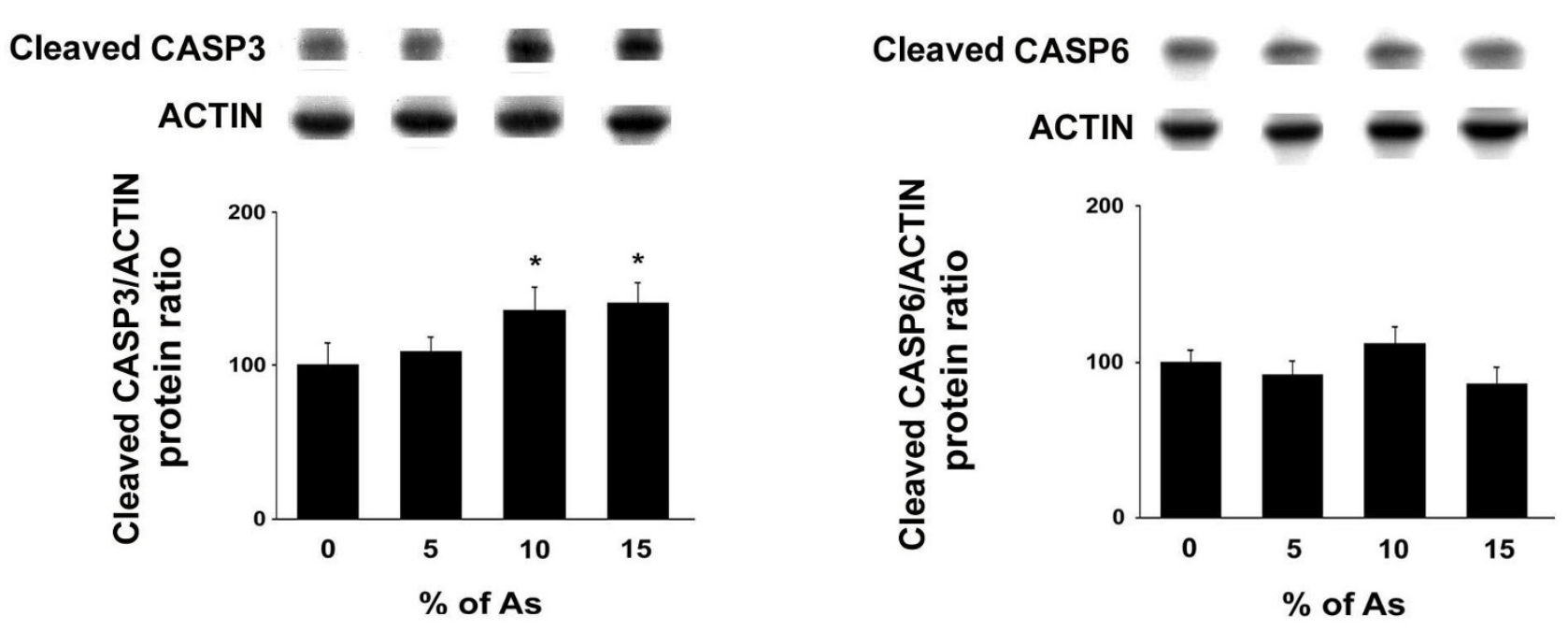

Figure 2

Quantitative effects of As administration on apoptosis in the testis (TUNEL and Western blotting). Adult rats were untreated $(0 \%)$ or fed with 5,10 and I5\% As. (A) The apoptotic rate represents the number of apoptotic germ cells (TUNEL approach) per Sertoli cells. (B) cleaved CASP3 and (C) cleaved CASP6 protein levels were analyzed through western blotting approach. The results are expressed as the mean \pm SD.

$15 \%(61 \% ; p<0.0001)$ of crude garlic (Fig. 4D). In contrast, the Srd5a2 (Fig. 4E) and Cyp19a1 (Fig. 4F) mRNA levels were unchanged after garlic treatment.

\section{Effects of As on Sertoli cell markers}

Some Sertoli markers such as GATA-4, GSTA2, TUBB3, AMH, RHOX5 and CDKN1B were evaluated (Fig. 5). Expression of GATA-4 protein levels was significantly $(p<$ 0.0001 ) increased at $10 \%$ and $15 \%$ doses of crude garlic (Fig. 5A). In contrast, GSTA2 (Fig. 5B), TUBB3 (Fig. 5C) or RHOX5 (Fig. 5E) expression was unchanged at different doses of As tested. The expression of AMH protein levels was significantly decreased after treatment with $10 \%$ (19.3\%; $p=0.007)$ and 15\% (24.1\%; $p=0.001)$ of As (Fig. 5D). Similarly, CDKN1B expression was significantly $(p<$
$0.0001)$ decreased at doses of $10 \%(31.3 \%)$ and $15 \%$ (45.6\%; Fig. 5F).

\section{Discussion}

Garlic has acquired a reputation as a formidable prophylactic and therapeutic medicinal agent over the centuries and many favorable experimental and clinical effects of the consumption of garlic, in different types of preparations (crude, powder...) have been reported (including cardiovascular diseases, stimulation of immune function, detoxification properties... for a review, see [3]). It has long been known, however, that the extraction process can increase potency compared with the crude plant. In the present study, the chemical analysis of the crude garlic used was not achieved, but Shukla and colleagues have 
A

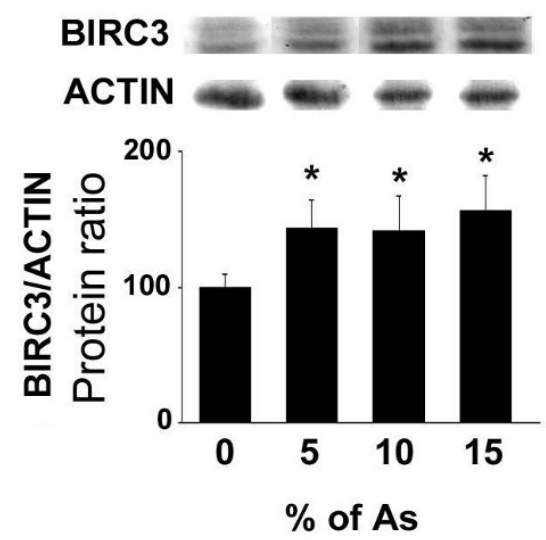

C
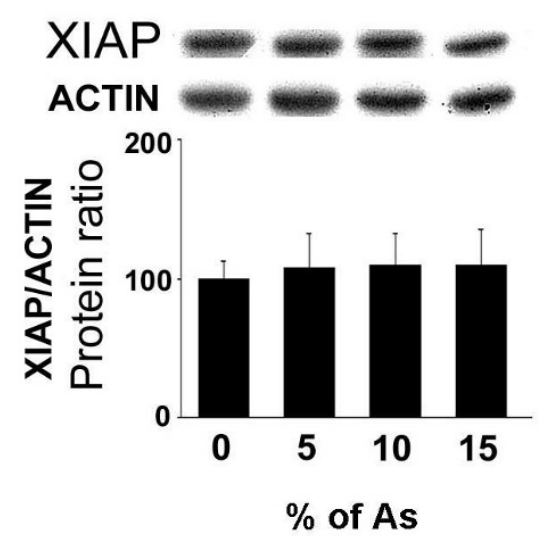

$\mathbf{E}$

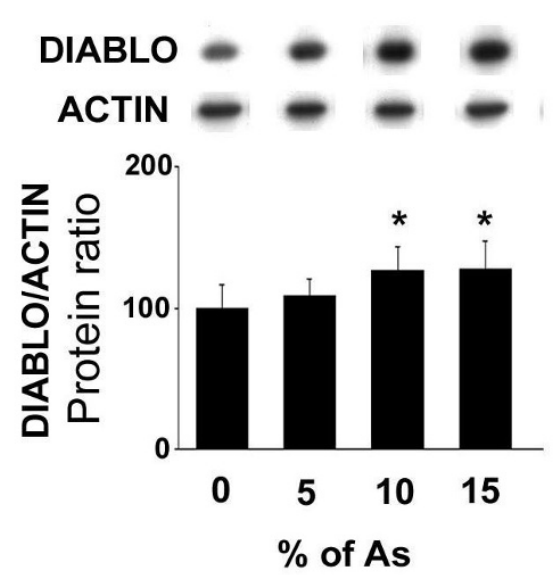

B

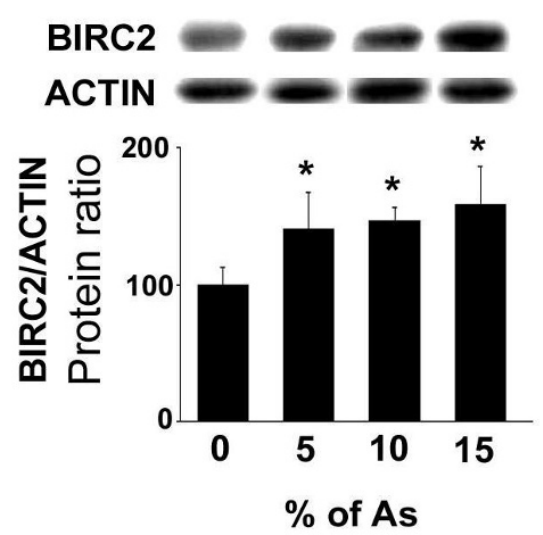

D

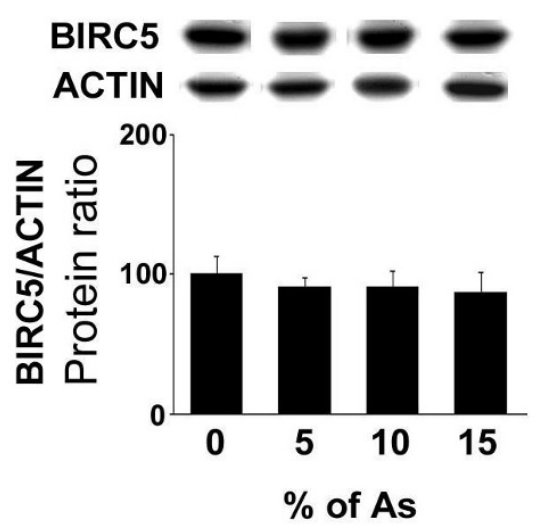

$\mathbf{F}$

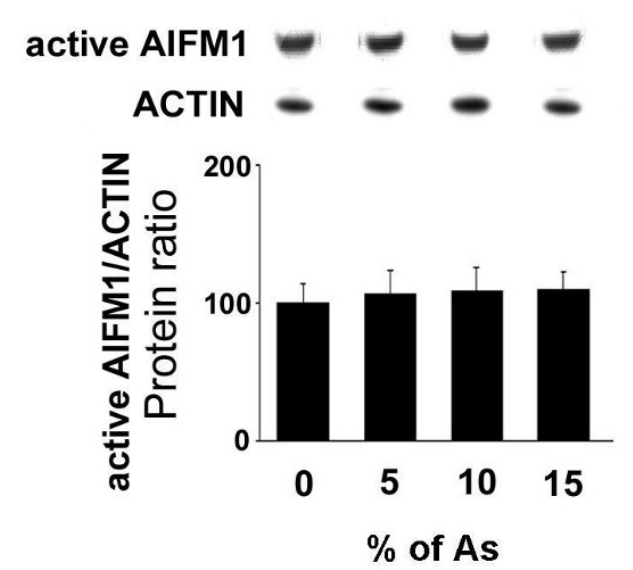

Figure 3

Effects of As administration on BIRC3, BIRC2, XIAP, BIRC5, DIABLO and active AIFMI protein levels (Western blotting). Adult rats were untreated (0\%) or fed with 5, 10 and I5\% As. (A) BIRC3, (B) BIRC2, (C) XIAP, (D) BIRC5, (E) DIABLO and (F) active AIFMI protein levels were analyzed through western blotting approach. In the upper panels, representative autoradiograms are shown. The results are expressed as the mean \pm SD. 
A
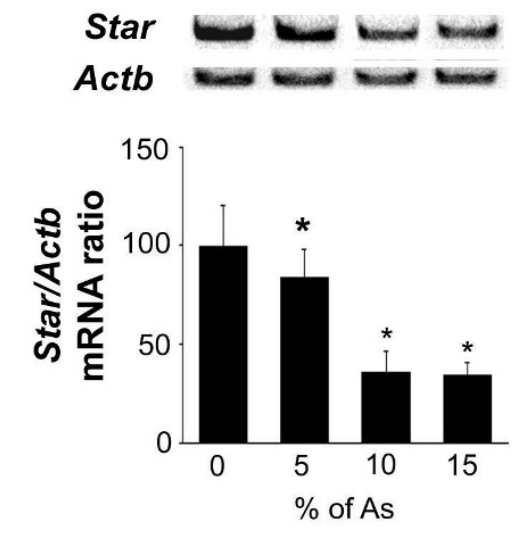

B
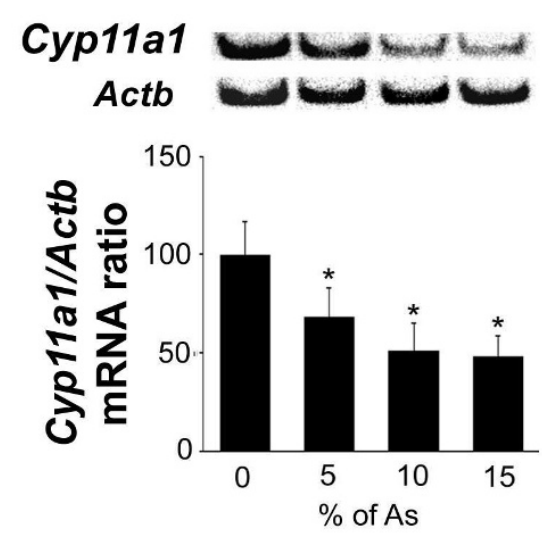

C
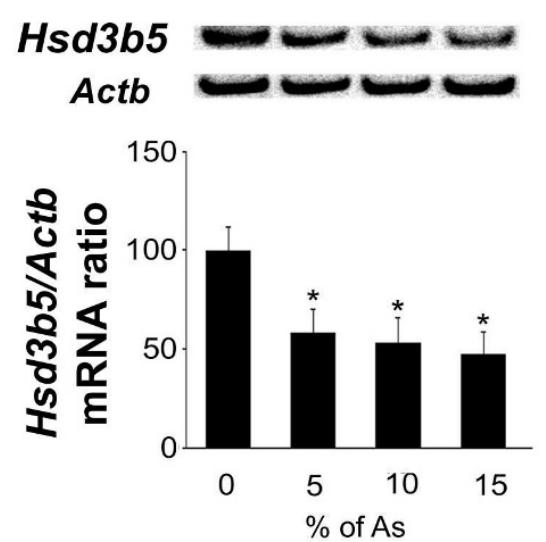

D
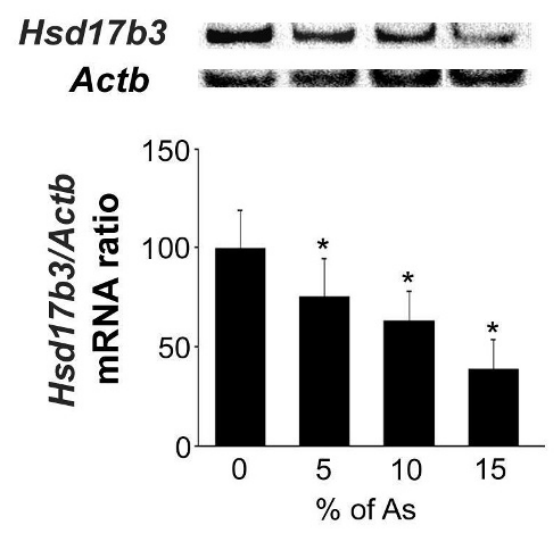

E
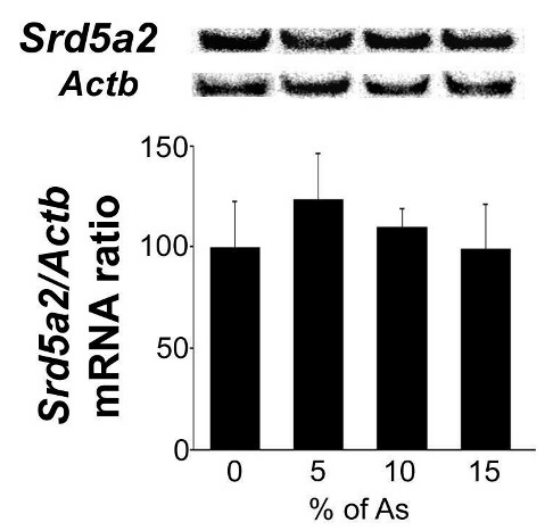

$\mathbf{F}$
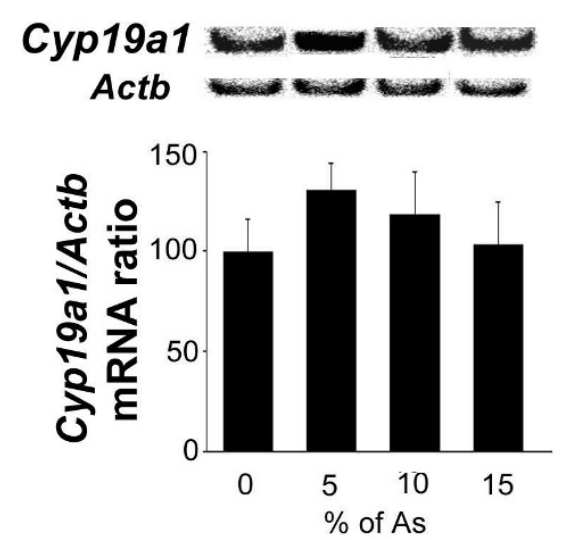

Figure 4

Effects of treatment with As on Leydig cell enzymes expression (RT-PCR). Adult rats were untreated (0\%) or fed with 5, 10, I5\% As. mRNA levels for (A) Star, (B) Cypl lal, (C) Hsd3b5, (D) HsdI 7b3, (E) Srd5a2 and (F) Cypl $9 a l$ were evaluated. In the upper panels representative autoradiograms are shown. The results are expressed as the mean \pm SD. 
A
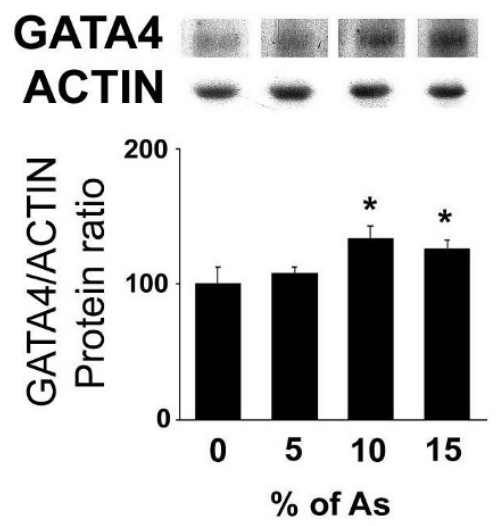

C

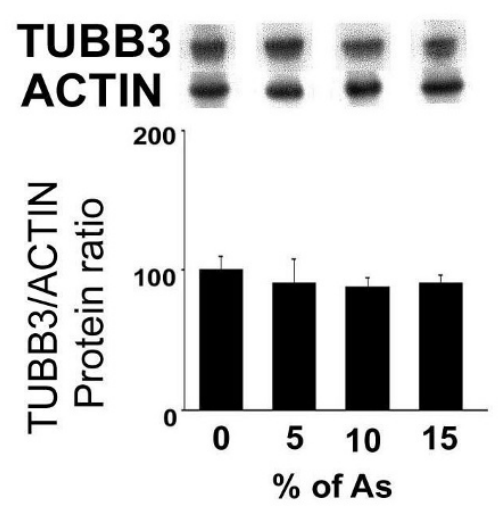

E

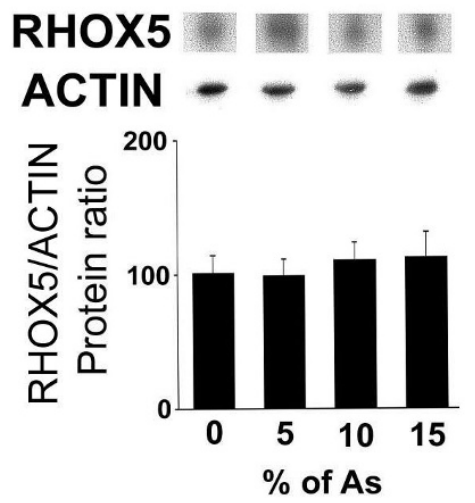

B
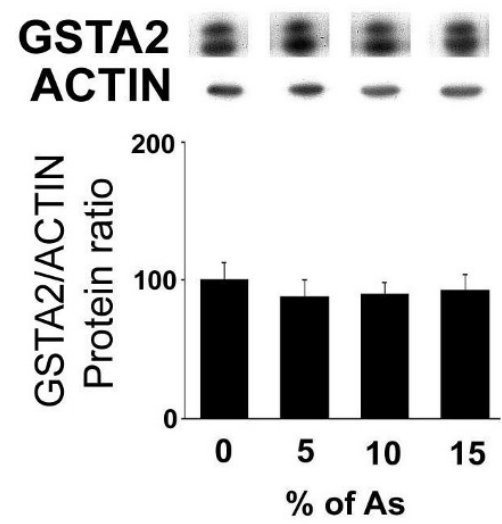

D

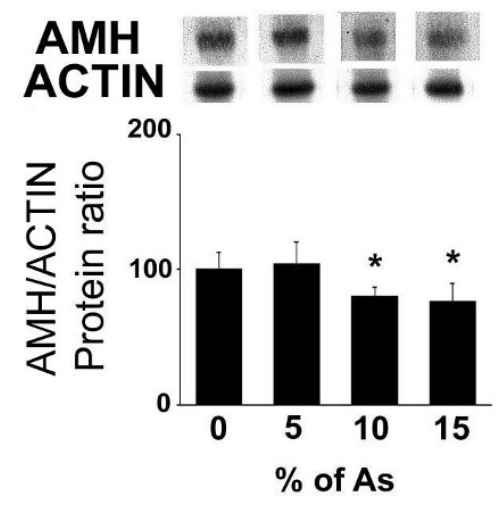

F

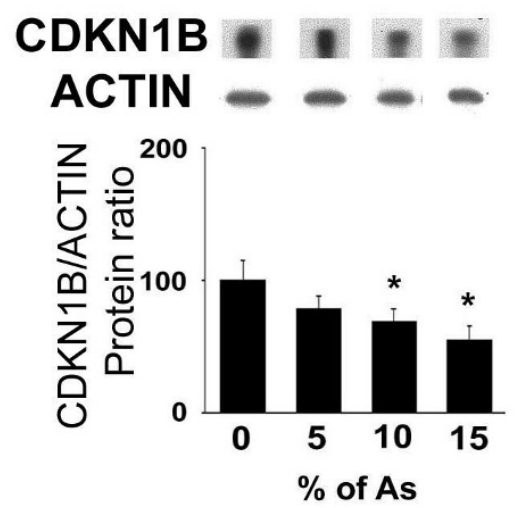

Figure 5

Effects of treatment with As on Sertoli cell markers' expression (Western blotting). Adult rats were untreated (0\%) or fed with 5, 10, I5\% As. Protein levels for (A) GATA-4, (B) GSTA2, (C) TUBB3, (D) AMH, (E) RHOX5 and (F) CDKNIB were evaluated. In the upper panels representative autoradiograms are shown. The results are expressed as the mean \pm SD 
quantified the concentration of the different compounds of garlic [9]. In this context, administration of garlic preparation to prevent hypercholesterolemia or arteriosclerosis might have side-effects on other organs. In terms of testicular functions, garlic or its metabolites have been studied as a protective adjuvant to different types of toxins [28]. Indeed, induction of testicular hypogonadism by heat is prevented in part by different types of garlic preparation (raw, heated garlic juices, dehydrated garlic powder of the more potent aged garlic extract [14]. Aqueous extract of garlic [29] or the metabolites diallyl sulfide [30] and diallyl tetrasulfide [31] offer a protection against cadmium-induced testicular damages. Garlic is also effective in restoring the testicular histology altered by EDTA [32]. The antioxidant activities of garlic extract were shown to decrease the toxic effects of free radicals induced by testicular torsion and detorsion [33]. While several studies show that As has a protective effect as an adjuvant, other studies show that it modifies spermatogenesis. Indeed, daily administration of $50 \mathrm{mg}$ garlic powder over 70 days induced a spermatogenetic arrest at spermatocyte I stage [15]. Moreover, aqueous garlic extract [17] or the metabolite diallyl trisulfide [18] have spermaticidal effects. In contrast, a 90-day administration of $100 \mathrm{mg} / \mathrm{kg}$ aqueous extract of garlic has been shown to increase the number of spermatozoa [34]. In this context, to assess the positive or negative effect of garlic, it was important to analyze its action on the different testicular functions through the study of germ cell apoptosis, Leydig cell steroidogenesis and Sertoli cell markers (the present study). The present study has focused on the effects of As on testicular cells and its mechanisms of action. We showed here that oral administration of crude garlic induced germ cell death that targeted spermatocytes and spermatids, whereas spermatogonia and somatic Leydig and Sertoli cells were not affected. Given that CASP3 was immunodetected mainly in spermatocyte and spermatid cells (the TUNEL-positive germ cells) and that As treatment, at the same doses as observed for TUNEL, induced a dose-dependent increase in active CASP3 protein levels, the possibility exists that the germ cell apoptotic process could be related to CASP3 activation. The germ cell death might also, however, be related to another programmed cell death process since CASP3 activation has been associated with differentiation in some cell types [35]. In contrast, the active effector CASP6 seemed not to be involved in our model, while proCASP6 is expressed in normal germ cells [36]. While it was previously reported that chronic administration of 50 mg of garlic powder induced an arrest of spermatogenesis, our present study shows, for the first time, the involvement of an apoptotic process that targets testicular germ cells. Very few, if any, studies have reported such an apoptotic effect of As on non-tumoral cells, although it has been described in tumoral cells [37]. For example, administration of crude extract of garlic to a human colon cancer cell line induced apoptosis by increasing the levels of BAX, CYCS (previously known as cytochrome c) and CASP3 activity while it decreased the mitochondrial membrane potential [38]. More specifically, raw crushed garlic is high in allicin, a powerful bioactive compound of garlic that induced activation of CASP3, CASP8 and CASP9 and cleavage of poly (ADP-ribose) polymerase in several cancer cells [39].

Given that the balance between pro-apoptotic molecules (active effector caspase, IAPs inhibitors) and anti-apoptotic molecules (IAPs) levels determines the fate of the cells towards the executioner step of the death process [21], we have evaluated the expression of IAPs in our experimental model. BIRC2 and BIRC3 are highly expressed in rat testes [40]. BIRC3 was detected in the nucleus of B spermatogonia, spermatocytes at different stages and of somatic cells while BIRC2 was localized in the cytoplasmic compartment of spermatocytes (from stage VI pachytene onwards), spermatids (round and elongated) and Leydig cells [41]. While BIRC2 and BIRC3 play a role in the protection of germ cells from Fas-mediated apoptosis [41], their increased expression after treatment with crude garlic (the present study) suggested that germ cells are unable to inhibit CASP3 action. A potential explanation is that the high levels of DIABLO (in spermatocytes) or HTRA2 in spermatids by inhibiting the IAP action may favor the activity of CASP3 in the germ cells mainly affected by apoptosis after As treatment. The other IAPs studied here were expressed for BIRC5 in spermatocytes at first meiotic prophase and highly in Leydig cells [42] or exclusively in Leydig cells (our unpublished data) and for XIAP mainly in Sertoli cells (our unpublished data). BIRC5 and XIAP levels were unchanged after As treatment, suggesting that Leydig (BIRC5) and Sertoli (XIAP) cells are not affected in terms of apoptosis by crude garlic administration. These data are in accordance with the TUNEL approach used in the present study.

DNA degradation might also be triggered by a caspaseindependent pathway through the action of AIFM1. During the apoptotic process, AIFM1 is released from mitochondria and translocated into the nucleus where its DNA binding activity mediates large-scale DNA fragmentation $[26,43]$. Given that As treatment, at the doses used in the present study, had no effect on the expression of active AIFM1, we suggest that the caspase-dependent pathway is mainly involved in our experimental model. The next question to address was whether germ cell death induced by As was related to modifications in hormone profile and/or Leydig and/or Sertoli cell markers.

Crude garlic induced a dose-dependent decrease in plasma and intratesticular testosterone concentrations in treated rats and an increase in LH levels [16], suggesting 
that As targeted Leydig cells. In this context, we evaluated the different steps of testosterone biosynthesis. Conversion of cholesterol to biologically active testosterone is a multi-step enzymatic process, including Star, that controls the transport of cholesterol from the outer to the inner mitochondrial membrane [44], Cyp11a1, Hsd17b3 and Hsd3b5. Testosterone can be metabolized by Srd5a2 or Cyp19a1. We showed here that As alters testosterone production, since we found that Star, Cyp11a1, Hsd17b3 and Hsd3b5 mRNA levels were decreased in a dose-dependent manner. Given that testosterone protects germ cells, especially spermatocytes and spermatids, against apoptosis [45-47], its decrease induced by As treatment might be an explanation for the death of spermatocyte and spermatid cells via an apoptotic process. Interestingly, while garlic extract is known to reduce serum cholesterol levels (in humans and animals) and inhibit cholesterol biosynthesis [48] testosterone production was not related to cholesterol metabolism [16] but to steroidogenic enzyme modification (the present study).

In terms of Sertoli cells, we showed here that both hormones which regulate cellular functions are decreased, i.e. testosterone and plasma FSH levels. In addition, the germ cell number might be decreased since the number of empty seminiferous tubules increased in a dose-dependent manner [16] and it is well recognized that germ cell loss modifies Sertoli cell functions (for a review, see [49]). In this context, we evaluated several Sertoli cell markers such as TUBB3, a housekeeping gene involved in cytosqueleton network [50] and expressed exclusively in Sertoli cells (our unpublished data), or proteins known to be regulated by testosterone (GSTA2, RHOX5, AMH, CDKN1B) and FSH (AMH) or known to be involved in paracrine interactions (GATA4). TUBB3 expression was unchanged at all doses of As used, suggesting an absence of effect of crude garlic on Sertoli cell number (the present study). These data are in accordance with the absence of apoptosis in Sertoli cells discussed above. In terms of androgen-dependent genes, we showed here that two of them (GSTA2 and RHOX5) have their expression unchanged after treatment. In contrast, $\mathrm{AMH}$ and CDKN1B expression was decreased while GATA-4 protein expression was significantly increased after feeding with crude garlic (the present study). Given that RHOX5 and GSTA2 expression (genes that possess ARE or ARE-like sequences) was unchanged, the possibility exists that As effects on AMH and CDKN1B are not linked to testosterone modifications but rather linked to germ cell loss. Altogether, these data indicate that As modifies some Sertoli cell markers. In the present experimental model, we observed decreased levels of testosterone associated with decreased levels of FSH. As suggested, the decreased plasma FSH levels could not be accounted for a central alteration since LH plasma levels were increased. It is noteworthy that the increase in plasma LH levels observed here was higher (about double at 10\% As and 3.3-fold at $15 \%$ As) than the decrease observed in FSH plasma levels (1.2-fold at 10 and 15\% As). Two hypotheses, however, might explain the discrepancies observed in the plasma gonadotropin levels. First, increased estradiol production has been shown to be associated with decreased plasma FSH without effects on LH production [51]. It is likely that in our experimental model the estradiol production was not modified since in the rats fed with crude garlic, the aromatase expression was not different compared with control animals. Second, Sertoli cells produce inhibin B which inhibits FSH secretion. Inhibin B expression is stimulated by FSH or germ cells (pachytene spermatocytes, early spermatids) and inhibited by testosterone. In the present study, the possibility exists that the dramatic decrease in testosterone production induces an increase in inhibin production that in turn decreases FSH plasma levels.

Raw garlic consumption by humans ranges from one to two cloves (about $4 \mathrm{~g}$ ) to $28 \mathrm{~g}$ per day (for a review, see [3]). The concentration used in the present study exceeds this amount of consumption, but various other types of garlic preparation are consumed (such as garlic powder, oil, extract or aged garlic) and the concentration in garlic active components is highly variable, particularly in powder and oil (for a review, see [3]). Moreover, the bioactive components of garlic are not fully characterized even if it is assumed that the sulfur-containing molecules are the active ones. Another point is that garlic consumption to reduce cardiovascular risk is a long-term consumption which is another potential negative effect with regard to spermatogenesis. In this context, and more widely, extrapolation from rat to human is a difficult task. It has long been known, however, that human spermatogenesis is more sensitive to stress than that of rats [52], suggesting that concentrations lower than those used in the present study might impair male spermatogenesis and, particularly, might induce azoospermia in men with low sperm count.

\section{Conclusion}

In summary, we showed that feeding with crude fresh crushed garlic has inhibitory effects on Leydig steroidogenic enzyme expression and Sertoli cell markers. These alterations might induce germ cell death (spermatocytes and spermatids) via an apoptotic process.

\section{Competing interests}

The authors declare that they have no competing interests.

\section{Authors' contributions}

IH carried out the molecular and biochemical studies. SA participated in the molecular and biochemical studies. 
$\mathrm{MB}$ participated in the design of the study and coordination. MEM performed the statistical analysis and helped to draft the manuscript. CM drafted the manuscript and participated in the design of the study. All authors read and approved the final manuscript.

\section{Acknowledgements}

This work was supported by the Institut National de la Santé et de la Recherche Médicale [U407], the Université Claude Bernard Lyon-I [UMR407], and the Tunisian Ministry of Superior Education and Scientific Research.

\section{References}

I. Agarwal KC: Therapeutic actions of garlic constituents. Med Res $\operatorname{Rev} 1996,16: 111-124$.

2. Tattelman E: Health effects of garlic. Am Fam Physician 2005, 72:103-106.

3. Amagase H, Petesch BL, Matsuura H, Kasuga S, Itakura Y: Intake of garlic and its bioactive components. I Nutr 200I, | 3 1:955S-962S.

4. Mahmoodi M, Islami MR, Asadi Karam GR, Khaksari M, Sahebghadam Lotfi A, Hajizadeh MR, Mirzaee MR: Study of the effects of raw garlic consumption on the level of lipids and other blood biochemical factors in hyperlipidemic individuals. Pak J Pharm Sci 2006, 19:295-298.

5. Yeh YY, Yeh SM: Garlic reduces plasma lipids by inhibiting hepatic cholesterol and triacylglycerol synthesis. Lipids 1994, 29:189-193.

6. Koscielny J, Klussendorf D, Latza R, Schmitt R, Radtke H, Siegel G, Kiesewetter $\mathrm{H}$ : The antiatherosclerotic effect of Allium sativum. Atherosclerosis 1999, 144:237-249.

7. Siegel G, Klussendorf D: The anti-atheroslerotic effect of Allium sativum: statistics re-evaluated. Atherosclerosis 2000, 1 50:437-438.

8. Galeone C, Pelucchi C, Levi F, Negri E, Franceschi S, Talamini R, Giacosa A, La Vecchia C: Onion and garlic use and human cancer. Am J Clin Nutr 2006, 84: 1027-1032.

9. Shukla Y, Kalra N: Cancer chemoprevention with garlic and its constituents. Cancer Lett 2007, 247:167-18I.

10. Chan KC, Yin MC, Chao WJ: Effect of diallyl trisulfide-rich garlic oil on blood coagulation and plasma activity of anticoagulation factors in rats. Food Chem Toxicol 2007, 45:502-507.

II. Steiner M, Li W: Aged garlic extract, a modulator of cardiovascular risk factors: a dose-finding study on the effects of AGE on platelet functions. J Nutr 200I, I 31 : 980 S-984S.

12. Silagy CA, Neil HA: A meta-analysis of the effect of garlic on blood pressure. J Hypertens 1994, I 2:463-468.

13. Ried K, Frank OR, Stocks NP, Fakler P, Sullivan T: Effect of garlic on blood pressure: a systematic review and meta-analysis. BMC Cardiovasc Disord 2008, 8: 13.

14. Kasuga S, Uda N, Kyo E, Ushijima M, Morihara N, Itakura Y: Pharmacologic activities of aged garlic extract in comparison with other garlic preparations. J Nutr 200I, 13 I: I080S-1084S.

15. Dixit VP, Joshi S: Effects of chronic administration of garlic (Allium sativum Linn) on testicular function. Indian J Exp Biol 1982, 20:534-536.

16. Hammami I, Nahdi A, Mauduit C, Benahmed M, Amri M, Ben Amar A, Zekri S, El May A, El May MV: The inhibitory effects on adult male reproductive functions of crude garlic (Allium sativum) feeding. Asian J Androl 2008, 10:593-60I.

17. Chakrabarti K, Pal S, Bhattacharyya AK: Sperm immobilization activity of Allium sativum $L$. and other plant extracts. Asian J Androl 2003, 5: | $3|-| 35$.

18. Qian YX, Shen PJ, Xu RY, Liu GM, Yang HQ, Lu YS, Sun P, Zhang RW, Qi LM, Lu QH: Spermicidal effect in vitro by the active principle of garlic. Contraception 1986, 34:295-302.

19. Hengartner MO: The biochemistry of apoptosis. Nature 2000, 407:770-776.

20. Clem RJ, Miller LK: Control of programmed cell death by the baculovirus genes p35 and iap. Mol Cell Biol 1994, 14:5212-5222.

21. Liston P, Fong WG, Korneluk RG: The inhibitors of apoptosis: there is more to life than Bcl2. Oncogene 2003, 22:8568-8580.
22. Vaux DL, Silke J: IAPs, RINGs and ubiquitylation. Nat Rev Mol Cell Biol 2005, 6:287-297.

23. Liston P, Fong WG, Kelly NL, Toji S, Miyazaki T, Conte D, Tamai K, Craig CG, McBurney MW, Korneluk RG: Identification of XAF I as an antagonist of XIAP anti-Caspase activity. Nat Cell Biol 200I, 3:128-133.

24. Liu Z, Sun C, Olejniczak ET, Meadows RP, Betz SF, Oost T, Herrmann J, Wu JC, Fesik SW: Structural basis for binding of Smac/DIABLO to the XIAP BIR3 domain. Nature 2000, 408:1004- 1008.

25. Wu G, Chai J, Suber TL, Wu JW, Du C, Wang X, Shi Y: Structural basis of IAP recognition by Smac/DIABLO. Nature 2000, 408: $1008-1012$.

26. Cande C, Cecconi F, Dessen P, Kroemer G: Apoptosis-inducing factor (AIF): key to the conserved caspase-independent pathways of cell death? J Cell Sci 2002, I I 5:4727-4734.

27. Mauduit C, Siah A, Foch M, Chapet O, Clippe S, Gerard JP, Benahmed M: Differential expression of growth factors in irradiated mouse testes. Int J Radiat Oncol Biol Phys 200I, 50:203-2I 2.

28. Oi Y, Imafuku M, Shishido C, Kominato Y, Nishimura S, Iwai K: Garlic supplementation increases testicular testosterone and decreases plasma corticosterone in rats fed a high protein diet. J Nutr 200I, 131:2150-2I56.

29. Ola-Mudathir KF, Suru SM, Fafunso MA, Obioha UE, Faremi TY: Protective roles of onion and garlic extracts on cadmiuminduced changes in sperm characteristics and testicular oxidative damage in rats. Food Chem Toxicol 2008, 46:3604-36II.

30. Sadik NA: Effects of diallyl sulfide and zinc on testicular steroidogenesis in cadmium-treated male rats. J Biochem Mol Toxicol 2008, 22:345-353.

31. Murugavel P, Pari L: Diallyl tetrasulfide modulates the cadmium-induced impairment of membrane bound enzymes in rats. J Basic Clin Physiol Pharmacol 2007, 18:37-48.

32. Khali WK, Ahmed KA, Park MH, Kim YT, Park HH, Abdel-Wahhab $M A$ : The inhibitory effects of garlic and Panax ginseng extract standardized with ginsenoside Rg3 on the genotoxicity, biochemical, and histological changes induced by ethylenediaminetetraacetic acid in male rats. Arch Toxicol 2008, 82: $183-195$.

33. Unsal A, Eroglu M, Avci A, Cimentepe E, Guven C, Derya Balbay M, Durak I: Protective role of natural antioxidant supplementation on testicular tissue after testicular torsion and detorsion. Scand J Urol Nephrol 2006, 40:17-22.

34. al-Bekairi AM, Shah AH, Qureshi S: Effect of Allium sativum on epididymal spermatozoa, estradiol-treated mice and general toxicity. J Ethnopharmacol 1990, 29: I I7-I25.

35. Miura M, Chen XD, Allen MR, Bi Y, Gronthos S, Seo BM, Lakhani S, Flavell RA, Feng XH, Robey PG, Young M, Shi S: A crucial role of caspase- 3 in osteogenic differentiation of bone marrow stromal stem cells. J Clin Invest 2004, I I 4: 1704- I7I3.

36. Omezzine A, Chater S, Mauduit C, Florin A, Tabone E, Chuzel F, Bars $R$, Benahmed M: Long-term apoptotic cell death process with increased expression and activation of caspase- 3 and -6 in adult rat germ cells exposed in utero to flutamide. Endocrinology 2003, | 44:648-66|.

37. Xiao D, Choi S, Johnson DE, Vogel VG, Johnson CS, Trump DL, Lee YJ, Singh SV: Diallyl trisulfide-induced apoptosis in human prostate cancer cells involves c-Jun $\mathbf{N}$-terminal kinase and extracellular-signal regulated kinase-mediated phosphorylation of Bcl-2. Oncogene 2004, 23:5594-5606.

38. Su CC, Chen GW, Tan TW, Lin JG, Chung JG: Crude extract of garlic induced caspase- 3 gene expression leading to apoptosis in human colon cancer cells. In Vivo 2006, 20:85-90.

39. Oommen S, Anto RJ, Srinivas G, Karunagaran D: Allicin (from garlic) induces caspase-mediated apoptosis in cancer cells. Eur J Pharmacol 2004, 485:97-103.

40. Holcik M, Lefebvre CA, Hicks K, Korneluk RG: Cloning and characterization of the rat homologues of the Inhibitor of Apoptosis protein I, 2, and 3 genes. BMC Genomics 2002, 3:5.

4I. Wang Y, Suominen JS, Parvinen M, Rivero-Muller A, Kiiveri S, Heikinheimo M, Robbins I, Toppari J: The regulated expression of cIAPI and c-IAP2 during the rat seminiferous epithelial cycle plays a role in the protection of germ cells from Fas-mediated apoptosis. Mol Cell Endocrinol 2005, 245: I I I- 120.

42. Wang $Y$, Suominen JS, Hakovirta H, Parvinen M, Martinand-Mari C, Toppari J, Robbins I: Survivin expression in rat testis is upregulated by stem-cell factor. Mol Cell Endocrinol 2004, 2 1 8: 165- 174. 
43. Joza N, Susin SA, Daugas E, Stanford WL, Cho SK, Li CY, Sasaki T, Elia AJ, Cheng HY, Ravagnan L, Ferri KF, Zamzami N, Wakeham A, Hakem R, Yoshida H, Kong YY, Mak TW, Zuniga-Pflucker JC, Kroemer G, Penninger JM: Essential role of the mitochondrial apoptosis-inducing factor in programmed cell death. Nature 200I, 41 0:549-554.

44. Stocco DM: Intramitochondrial cholesterol transfer. Biochim Biophys Acta 2000, I 486:184-197.

45. Bakalska M, Atanassova N, Koeva Y, Nikolov B, Davidoff M: Induction of male germ cell apoptosis by testosterone withdrawal after ethane dimethanesulfonate treatment in adult rats. Endocr Regul 2004, 38: I03-I I0.

46. Tesarik J, Greco E, Cohen-Bacrie P, Mendoza C: Germ cell apoptosis in men with complete and incomplete spermiogenesis failure. Mol Hum Reprod 1998, 4:757-762.

47. Woolveridge I, de Boer-Brouwer M, Taylor MF, Teerds KJ, Wu FC, Morris ID: Apoptosis in the rat spermatogenic epithelium following androgen withdrawal: changes in apoptosis-related genes. Biol Reprod 1999, 60:46 I-470.

48. Campbell JH, Efendy JL, Smith NJ, Campbell GR: Molecular basis by which garlic suppresses atherosclerosis. J Nutr 200I, 131:1006S-1009S.

49. O'Shaughnessy PJ, Hu L, Baker PJ: Effect of germ cell depletion on levels of specific mRNA transcripts in mouse Sertoli cells and Leydig cells. Reproduction 2008, I35:839-850.

50. Slaughter GR, Meistrich ML, Means AR: Expression of RNAs for calmodulin, actins, and tubulins in rat testis cells. Biol Reprod 1989, 40:395-405.

5I. D'Souza R, Gill-Sharma MK, Pathak S, Kedia N, Kumar R, Balasinor N Effect of high intratesticular estrogen on the seminiferous epithelium in adult male rats. Mol Cell Endocrinol 2005, 24I:4I-48.

52. Meistrich ML, Samuels RC: Reduction in sperm levels after testicular irradiation of the mouse: a comparison with man. Radiat Res 1985, 102:138-147.

Publish with Bio Med Central and every scientist can read your work free of charge

"BioMed Central will be the most significant development for disseminating the results of biomedical research in our lifetime. "

Sir Paul Nurse, Cancer Research UK

Your research papers will be:

- available free of charge to the entire biomedical community

- peer reviewed and published immediately upon acceptance

- cited in PubMed and archived on PubMed Central

- yours - you keep the copyright

Submit your manuscript here:

http://www.biomedcentral.com/info/publishing_adv.asp
BioMedcentral 